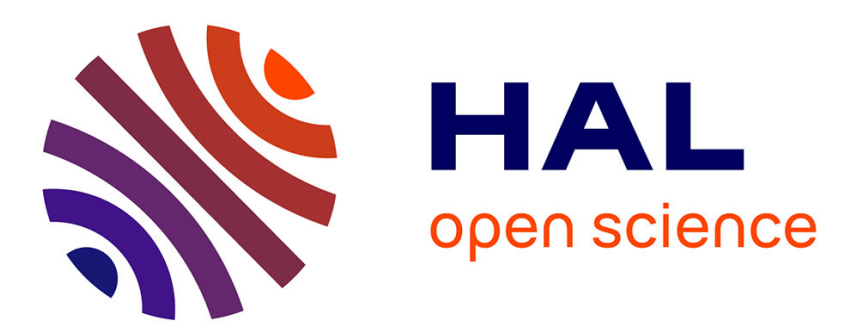

\title{
Effects of some physical factors and agricultural practices on Collembola in a multiple cropping programme in West Bengal (India)
}

Ipsa Bandyopadhyaya, Deb Kumar Choudhuri, Jean-François Ponge

\section{To cite this version:}

Ipsa Bandyopadhyaya, Deb Kumar Choudhuri, Jean-François Ponge. Effects of some physical factors and agricultural practices on Collembola in a multiple cropping programme in West Bengal (India). European Journal of Soil Biology, 2002, 38 (1), pp.111-117. 10.1016/S1164-5563(01)01114-1 . hal00499487

\section{HAL Id: hal-00499487 https://hal.science/hal-00499487}

Submitted on 9 Jul 2010

HAL is a multi-disciplinary open access archive for the deposit and dissemination of scientific research documents, whether they are published or not. The documents may come from teaching and research institutions in France or abroad, or from public or private research centers.
L'archive ouverte pluridisciplinaire HAL, est destinée au dépôt et à la diffusion de documents scientifiques de niveau recherche, publiés ou non, émanant des établissements d'enseignement et de recherche français ou étrangers, des laboratoires publics ou privés. 


\section{EFFECTS OF SOME PHYSICAL FACTORS AND AGRICULTURAL PRACTICES ON COLLEMBOLA IN A MULTIPLE CROPPING PROGRAMME IN WEST BENGAL (INDIA)}

Ipsa Bandyopadhyaya ${ }^{a}$, D.K. Choudhuri ${ }^{b}$ and Jean-Francois Ponge ${ }^{c *}$

asiksha Satra, Visva Bharati, Sriniketan, 731236, W.B., India

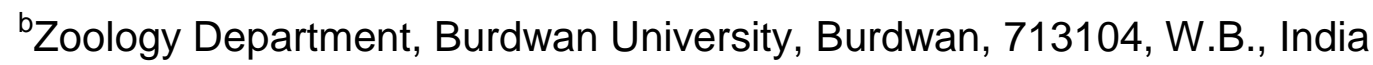

'Laboratoire d'Ecologie Generale, Museum National d'Histoire Naturelle, 4,avenue du Petit-Château, 91800, Brunoy, France.

*Corresponding author, fax: +33 1 60465009, e-mail: jeanfrancois.ponge@wanadoo.fr

Running title: Collembolan fauna in a multiple cropping programme 


\section{Abstract:}

Collembolan populations were followed monthly for three years in a long-term cultivated and fertilized agricultural field in East India (West Bengal), in which three crops (jute, paddy rice and wheat) were cultivated and subjected to various doses of NPK fertilizers, herbicides and organic manure. Each crop showed a rise followed by a decrease in Collembolan populations. Crossed with crop effects Collembolan populations showed a negative correlation with soil temperature and and a positive correlation with soil moisture. Application of organic manure induced the highest populations but the effects of fertilization and other treatments applied to the field were smaller than seasonal and crop influences.

Keywords: Collembola/physical factors/agricultural practices.

\section{INTRODUCTION:}

Soil animals promote the decomposition of organic matter by comminuting litter, interacting with microbes, recycling nutrients $[6,35,1]$ and making them available for uptake by an autotrophic plant community [27]. Soil animals are directly associated with the soil structure through fecal deposition and drilling of pores [22]. Any human interference such as agricultural practices including conventional tillage, use of pesticides which interferes with the composition of soil communities and reduce the abundance of soil invertebrates $[30,23]$ may reduce process rates in the soil [33]. Considerable attention has been paid to the effects of agricultural practices on soil fauna, especially microarthropods, mainly represented by mites and collembola [13, 
12, 25]. Research efforts concerning tropical countries are still in progress and more knowledge is needed before more conservative methods can be applied to the management of agricultural soils.

The present experiment was conducted to study the Collembolan population of agricultural fields in which three crops (jute, paddy rice and wheat) were cultivated and supplemented with graded doses of $\mathrm{N}, \mathrm{P}$, and $\mathrm{K}$ fertilizers. Treatments were also designed to estimate the effects of organic manure and herbicides.

\section{MATERIALS AND METHODS:}

Experimental plots were selected at the Jute Agricultural Research Institute (I.C.A.R.), Barrackpore, West Bengal, India $\left(22^{\circ} 46^{\prime} \mathrm{N}, 88^{\circ} 24^{\prime} \mathrm{E}\right)$, in a long-term (15-yr) fertilizer experiment. In this experiment, three croppping systems using jute, paddy rice and wheat succeeded round the year. Nine different treatments (Table I) were replicated four times using a randomised block design. Soil samples were collected from experimental plots at monthly intervals for three consecutive years. Plot size was $20 \mathrm{~m} \times 10 \mathrm{~m}$.

The soil was alluvium from the Gangetic plain. Fertilizer sources for NPK treatment were urea, superphosphate and potassium chloride, respectively. The three crop rotations consisted of two cereals, paddy rice (Oryza sativa L.) and wheat (Triticum aestivum L.) and one fibre crop, jute (Corchorus olitorius L.). Jute was sown in April and harvested in July. Paddy rice was transplanted in August and harvested in November. Wheat was sown in December and harvested in March. 
Hand weeding and hoeing were done at monthly intervals after sowing or transplanting. A herbicide was used for weed control in treatment 7. Soil samples were collected from all replicated plots at monthly intervals. Samplers were $9 \mathrm{~cm}$ long and with a cross sectional area of $28 \mathrm{~cm}^{2}$. Three cores were taken from each plot, at each time. Tullgren funnel extractors were used for collecting soil microarthropods. The extraction time was five days. Soil temperature, surface humidity and soil moisture were recorded each month from all replicated plots under each treatment.

After extraction, animals were mounted in polyvinylalcohol and identified to the species or to the genus level under a phase contrast microscope. In the absence of a comprehensive account of Indian springtails, half of the species could only be identified at the genus level.

Data pooled over three years for each experimental plot were used for the calculation of Spearman rank correlation coefficients, a posteriori comparisons among means using t-tests or non-parametric Kolmogorov-Smirnov tests according to normality of residuals [32] and correspondence analysis [16]. For correspondence analysis, data were transformed using refocusing (mean fixed to 20) and reweighting (variance fixed to 1) and variables were doubled in higher and lower values according to Ponge and Delhaye [28]. The latter procedure allowed to display changes in population densities. Each variable was thus represented by two points (higher and lower values) which were symmetrical around the origin. The farther these points were from the origin in the direction of a given axis, the better the corresponding variable contributed to this axis. Main (active) variables were Collembolan taxa (densities) and 
additional (passive) variables were crops (wheat, paddy rice or wheat), total abundance of Collembola, temperature, moisture, relative humidity and months (January to December).

\section{RESULTS:}

Eleven Collembolan species (Table 2) were found in this experiment of which Isotomurus balteatus and Cryptopygus thermophilus were most common.

The first two axes of correspondence analysis explained $29 \%$ and $23 \%$ of the total variance, respectively (Figure 1). Axis 1 was interpreted as a global trend of decreasing abundance of the Collembolan population, depending mainly on temperature and, to a lesser extent, relative humidity and moisture, judging from the corresponding loadings (Table 3). Axis 2 expressed detail changes in species composition, but no proper explanation was found for this axis. Thus it will not be accounted for in the following. The position of months, projected as additional (passive) variables, in the plane of axes 1 and 2, but more especially along axis 1 , showed that January, February, July, September, October and November exhibited an abundant Collembolan fauna, while these animals were scarce in March, April, May, June, August and December (Figures 1 and 2). Jute was the crop with the lowest Collembolan population, while paddy rice and wheat had more animals, as was indicated by the position of corresponding additional variables in the plane of axes 1 and 2 (Figure 1) and by monthly data (Figure 2). The population of Collembola was highest during February followed by October. Collembola were thus at a maximum during paddy rice cultivation when soil temperature was low and the 
moisture content of the soil was high (Figure 3). A Spearman rank correlation coefficient showed a significant negative correlation with temperature $\left(r_{s}=-0.41\right)$ and a significant but weaker positive correlation with moisture $\left(r_{s}=0.30\right)$. No significant correlation was found with relative humidity $\left(r_{s}=0.12\right)$. Waves of increases and decreases of Collembolan populations followed the development of cultivated vegetation (Figure 2). Wheat cultivation started in December, with a low population which increased to a maximum during February, then collapsed in March (differences between February and March total densities significant according to KolmogorovSmirnov test). Jute also started with a low population in April and May, which increased until July, after that a collapse (differences in total densities not significant) was observed in August at the start of paddy cultivation. Under paddy rice the Collembolan population increased until October, then decreased in November (not significant) and more abruptly in December(significant).

In relation to the application of fertilizer and organic manure, it was observed that treatment T6, receiving organic manure (farmyard manure) during jute cultivation in addition to moderate doses of NPK fertilizer, encouraged the highest development of Collembolan population (Figure 4). The treatment T3, with moderate doses of NPK, could be considered as a control for T6 and exhibited a lower population, although a t-test exhibited a weak level of significance $(P=0.06)$. The next highest population of Collembola was observed in the control (T8) plot. T1, receiving the lowest dose of NPK fertilizer, supported the same total population as T2 which received the highest dose of fertilizer. The lowest Collembolan population was observed in the treatment T9 (fallow) followed by T5 which received only $\mathrm{N}$ fertilizer and was devoid of $\mathrm{P}$ and 
K.No effect of herbicide treatment was observed, if we compare T7 (with herbicide) with the control T8 (Figure 4).

\section{DISCUSSION:}

Low numbers of Collembola (Table 3 ) in this long term cultivated and fertilized field (15 years) agrees with the observations that, compared to cultivated land, uncultivated and undisturbed land had more Collembolan fauna [12, 7, 23]. Arable land has no vegetation during a period whereas uncultivated land ensures a continuous food supply through litter deposition and root exudates [5]. Conventional tillage, such as deep plowing and heavy machinery use, has an adverse effect on Collembola $[20,21]$.

The maximum population of Collembola was in February (Spring) followed by October (Autumn), as has been already observed in other studies done in India [7, 31]. The decrease in the density of soil animals after cultivation resulted from a drop in organic matter content following a period of intense biological activity [15]. Such reduction of soil animal populations has been observed immediately following cultivation [34]. Agricultural operations like plooughing and harrowing generally decrease the abundance of soil animals $[15,11,2]$. Crop rotation causes a decline in the number of soil animals compared with continuous cropping [12]. The present investigation was carried out under a high cropping intensity round the year and the soil was prepared three times in a year before planting the crops with power tillage implements. Conventional tillage utilizing a moldboard plow significantly reduces Collembola immediately following its use [24]. In the present experiment it was 
observed that after harvesting of one crop the next crop started with lower Collembolan fauna and then increased gradually (Figure 2).

A higher organic matter content is usually beneficial for most animal groups [2]. The same beneficial effect of organic matter was observed here under the influence of farmyard manure. The plot which received farmyard manure showed a higher population than the control plot as already observed by Curry and Purvis [9]. The organic matter is crucial for the stability of the soil structure and it serves as an energy source for microorganisms which mesofauna consume [12]. The beneficial effects of manure recorded here could be thought at first sight to be due to the fact that manure itself contains high numbers of soil microarthropods [8], but it should be noticed that some species abundant in manure such as Xenylla welchi were never found in our collections.

In the present experiment the abundance of Collembola did not seem to vary to a great extent according to the dose of NPK fertilizer applied to the soil. This result contradicts the observation that any sort of fertilizer tend to increase the number of soil Collembola [14]. The plot T5 receiving $\mathrm{N}$-fertilizer only showed a lower Collembolan population. A similar depressive effect has been reported on earthworms by Deleporte and Tillier [10]. Urea was the source of nitrogen in the present experiment. The long-term use of urea was found to decrease soil $\mathrm{pH}$, through increase in nitrate ions [4]. The acidity of soil exerts a profound influence on many Collembolan species $[3,19,17,18]$. Nitrogen fertilizer alone was also thought to create a too high osmotic pressure in the soil solution which has a negative effect 
on the abundance of soil animals [2]. Herbicide (atrazine) exerted no adverse effect on Collembola as reported in other studies [26, 29].

Nevertheless we observed that, in the conditions of West Bengal agriculture (strong climate variations and multiple cropping within a year), the influence of crop changes and seasonal variations in temperature was much more pronounced than that of fertilizer and herbicide treatments.

\section{ACKNOWLEDGEMENTS:}

The authors are thankful to Dr. S.K. Mitra, Joint Director of Zoological Survey of India for his suggestion and help in identifying the Collembola.

\section{REFERENCES:}

[1] Anderson J.M., Flanagan P.W., Tropical soil biology and fertility, A handbook of methods, $1^{\text {st }}$ ed., CAB International, Wellingford, 1989.

[2] Andrén O., Lagerlof J., Soil fauna (Microarthropods, Enchytraeids and Nematodes) in Swedish agricultural cropping system, Acta Agric. Scand. (1983) 1-33.

3] Baath E., Berg B., Lohm L., Lundgren B, Lundkvist H., Rosswall T.,Söderström B, Wiren A., Effect of experimental acidification and liming on soil organisms and decomposition in Scot pine forest, Pedobiologia 20 (1980) 85-106. 
[4] Brady N.C., Weil R.R., The nature and properties of soils, 12th ed., Prentice Hall, Upper Saddle River, 1999.

[5] Buckle P., A preliminary survey of the soil fauna on agricultural lands, Ann. Appl. Biol. 8 (1921) 135-145.

[6] Butcher J.W., Snider R.M., Snider R.J., Bioecology of edaphic Collembola and Acarina, Ann. Rev. Entomol. 16 (1971) 249-288.

[7] Choudhuri D.K., Roy S., The Collembola (Insecta) of uncutivated fields in Burdwan district (West Bengal) with remarks on correlation between monthly population and certain soil factors, Proc.Zool. Soc. Calcutta 24 (1971) 33-39.

[8] Curry J.P., The arthropod fauna associated with cattle manure applied as slurry to grassland, Proc. Ir. Acad. Ser.B. 79 (1979) 15-27.

[9] Curry J.P., Purvis G., Studies on the influence of weed and farmyard manure on the arthropod fauna of suger beet, J. Life Sci. Royal Dublin Soc. 3 (1982) 397408.

[10] Deleporte S., Tillier P., Long-term effects of mineral amendments on soil fauna and humus in an acid beech forest floor, For. Ecol. Manag. 118 (1999) 245252. 
[11] Edwards C.A., Investigations on the influence of agricultural practice on soil invertebrates, Ann. Appl. Biol. 87 (1977) 515-520.

[12] Edwards C.A., Lofty J.R., The influence of agricultural practice on soil microarthropod populations, in: Sheals J.G. (Ed.),The Soil Ecosystem, Systemic Association, London, 1969, pp. 237-247.

[13] Frampton G. K., Recovery responses of soil surface Collembola after spatial and temporal changes in long-term regimes of pesticide, Pedobiologia 44 (2000) 489-501.

[14] Franz H., Der ein verschiedener Dungungmassnahmen auf die Bodenfauna, Angew. Pflanzensoziol. 11 (1953) 1-50.

[15] Ghilarov H.,1975 General trends of changes in soil animal populations of arable land, in: Vanek J. (Ed.), Progress in soil zoology, Czechoslovak Academy of Sciences, Prague, 1984, pp. 31-39.

[16] Greenacre M.J., Theory and applications of correspondence analysis, Academic Press, London, 1984.

[17] Hågvar S., Effect of liming and artificial acid rain on Collembola and Protura in coniferous forest, Pedobiologia, 27 (1984) 341-354. 
[18] Hågvar S., Ecological studies on microarthropods in forest soils, with emphasis on relation to soil acidity, University of Oslo, Oslo,1984.

[19] Hågvar S., Abrahamsen G., Colonisation by Enchytraeidae, Collembola and Acarina in sterile soil samples adjusted with pH levels, Oikos, 34 (1980) 245258.

[20] Heisler C., Influence of texture damage by mechanical loads on species diversity of springtails in conventional tillaged arable land (Collembola), Entomol. Gener. 16 (1991) 39-52.

[21] Kracht M., Schrader S., Collembola and Acari in compacted soil of agricultural land under different soil tillage systems, Braunschw. Naturkundl. Schr. 5 (1997) 425-440.

[22] Lavelle P., Spain A., Blanchart E., Marti A., Martin S., Schaefer R., The impact of soil fauna on the properties of soils in the humid tropics, in : Lal R., Sanchez P. (Eds.) Myths and science of soils of the tropics, Soil Sciense Society of America, Washington,1992.

[23] Loranger G, Ponge J.F., Blanchart E., Lavelle P., Influence of agricultural practices on arthropod communities in a vertisol (Martinique), Eur. J. Soil Biol. 34 (1998) 157-165. 
[24] Mallow D., Snider R.J., Robertson L.S., Effect of different management practices on Collembola and Acarina in corn production systems. II. The effects of moldboard plowing and atrazine, Pedobiologia 28 (1985) 115-131.

[25] Marshall V.J., Effects of manure and fertilizers on soil fauna: a review, CAB Special Publication 3 (1977) 1-79.

[26] Moore J.C., Snider R.J., Robertson L.S., Effect of different management practices on Collembola and Acarina in corn production system. I. The effect of no tillage and atrazine, Pedobiologia 26 (1984) 143-152.

[27] Ponge J.F., Interaction between soil fauna and their environment, in: Rastin N., Bauhus J. (Eds.), Going underground. Ecological studies in forest soil, Research Signpost,Trivandrum, 1999, pp. 45-76.

[28] Ponge J.F., Delhaye L., The heterogeneity of humus profiles and earthworm communities in a virgin beech forest, Biol. Fertil.Soils, 20 (1995) 24-32.

[29] Rapoport E.H., Canglioli G., Herbicide and the soil fauna, Pedobiologia 2 (1963) 235-238.

[30] Reddy M.V., Reddy V.R., Yule D.F., Cogle A.L., George P.J., Decomposition of straw in relation to tillage, moisture and arthropod abundance in semi-arid tropical Alfisol, Biol. Fertil. Soils 17 (1994) 45-50. 
31]Sinha P.B., Sen N.S., Jafri H.A., On the seasonal population fluctuation of Collembola and Acarina in a deciduous forest at Ranchi (India), J. Environ. Biol. 9 (1988) 79-83.

[32] Sokal R.R., Rohlf F.J., Biometry. The principles and practice of statistics in biological research, $3^{\text {rd }}$ ed., W.H. Freeman and Company, New York, 1995.

[33] Storke N.E., Eggleton P., Invertebrates as determinants and indicators of soil quality, Am. J. Altern. Agric. 7 (1992) 38-47.

[34] Tischler W., Effects of agricultural practices on the soil fauna, in: Kevan D.K. McE. (Ed.), Soil zoology, Butterworths, London, 1955, pp. 215-230.

[35] Wallwork J.A., The distribution and diversity of soil fauna, Academic Press, London, 1976. 


\section{Legends of figures}

Figure 1. Correspondence analysis. Projection of Collembolan species (three-letter codes) as active variables and additional variables in the plane of axes 1 and 2 . Higher values of variables were indicated by bold type, lower values by italic type

Figure 2. Abundance of Collembola in relation to months and crops.

Figure 3. Changes in temperature and moisture in different months.

Figure 4. Abundance of Collembola in relation to different treatments. 
Table 1. Treatments showing the different doses of fertilizers, farmyard manure (FYM), chemical weeding (CW) and hand weeding (HW) during three crops

\begin{tabular}{llll}
\hline & JUTE & PADDY & WHEAT \\
\hline T1 & N30P15K30+HW & N60P30K30+Hoeing & N60P30K30+Hoeing \\
T2 & N90P45K90+HW & N180P90K90+Hoeing & N180P90K90+Hoeing \\
T3 & N60P30K60+HW & N120P60K60+HW+Hoeing & N120P6OK60+HW+Hoeing \\
T4 & N60P30K0+HW & N12OP60K0+Hoeing & N120P60K0+Hoeing \\
T5 & N60P0K0+HW & N120POK0+Hoeing & N120POK0+Hoeing \\
T6 & N60P30K60+FYM10ton/ha+HW N120P60K60+Hoeing & N120P60K60+Hoeing \\
T7 & N60P30K60+CW & N120P60K60+CW & N120P60K60+CW \\
T8 & NOP0K0(control)+HW & NOPOK0(control)+Hoeing & NOPOKO(control)+Hoeing \\
T9 & Fallow & Fallow & Fallow \\
\hline
\end{tabular}


Table 2. Collembolan species/genera found in the experiment, with their mean densities per unit surface

\begin{tabular}{lll}
\hline Code Species name & Densities. $\mathrm{m}^{-2}$ \\
\hline IBA & Isotomurus balteatus & 86.73 \\
CTH & Cryptopygus thermophilus & 53.46 \\
LSP Lepidocyrtus sp. & 22.37 \\
CJA Cyphoderus javanus & 24.27 \\
SIN Seira indica & 3.00 \\
SAP Sminthurides appendiculatus 1.09 \\
BSP Brachystomella sp. & 6.00 \\
SSP Sminthurus sp. & 4.91 \\
SCO Sphaeridia cornuta & 0.55 \\
ISP Isotomodes sp. & 1.09 \\
ASP Acherontiella sp. & 0.55 \\
\hline
\end{tabular}


Table 3. Correspondence analysis. Loadings of the variables according to the first two factorial axes. For doubled variables codes for higher values are in bold type while lower values are in italic type

\begin{tabular}{|c|c|c|}
\hline Variables & Axis 1 & Axis 2 \\
\hline IBA & -0.041 & -0.011 \\
\hline CTH & -0.028 & 0.032 \\
\hline LSP & -0.039 & -0.001 \\
\hline CJA & -0.007 & -0.025 \\
\hline SIN & 0.013 & 0.002 \\
\hline SAP & 0.023 & -0.026 \\
\hline BSP & -0.026 & -0.024 \\
\hline SSP & 0.017 & 0.028 \\
\hline sco & 0.023 & -0.026 \\
\hline ISP & 0.019 & 0.034 \\
\hline ASP & -0.026 & 0.015 \\
\hline$I B A$ & 0.041 & 0.011 \\
\hline CTH & 0.028 & -0.032 \\
\hline$L S P$ & 0.039 & 0.001 \\
\hline CJA & 0.007 & 0.025 \\
\hline SIN & -0.013 & -0.002 \\
\hline$S A P$ & -0.023 & 0.026 \\
\hline$B S P$ & 0.026 & 0.024 \\
\hline$S S P$ & -0.017 & -0.028 \\
\hline SCO & -0.023 & 0.026 \\
\hline$I S P$ & -0.019 & -0.034 \\
\hline$A S P$ & 0.026 & -0.015 \\
\hline Abundance & -0.044 & -0.002 \\
\hline Relative humidity & 0.008 & -0.014 \\
\hline Temperature & 0.030 & 0.011 \\
\hline Moisture & -0.006 & -0.005 \\
\hline Abundance & 0.044 & 0.002 \\
\hline Relative humidity & -0.008 & 0.014 \\
\hline Temperature & -0.030 & -0.011 \\
\hline Moisture & 0.006 & 0.005 \\
\hline Wheat & -0.009 & -0.011 \\
\hline Jute & 0.023 & 0.028 \\
\hline Paddy & -0.009 & -0.003 \\
\hline January & -0.007 & -0.006 \\
\hline February & -0.044 & -0.020 \\
\hline March & 0.017 & 0.000 \\
\hline April & 0.028 & 0.045 \\
\hline May & 0.017 & 0.028 \\
\hline June & 0.019 & -0.003 \\
\hline July & -0.010 & -0.029 \\
\hline August & 0.040 & -0.041 \\
\hline September & -0.003 & 0.002 \\
\hline October & -0.046 & 0.023 \\
\hline November & -0.019 & 0.006 \\
\hline December & 0.007 & -0.005 \\
\hline
\end{tabular}




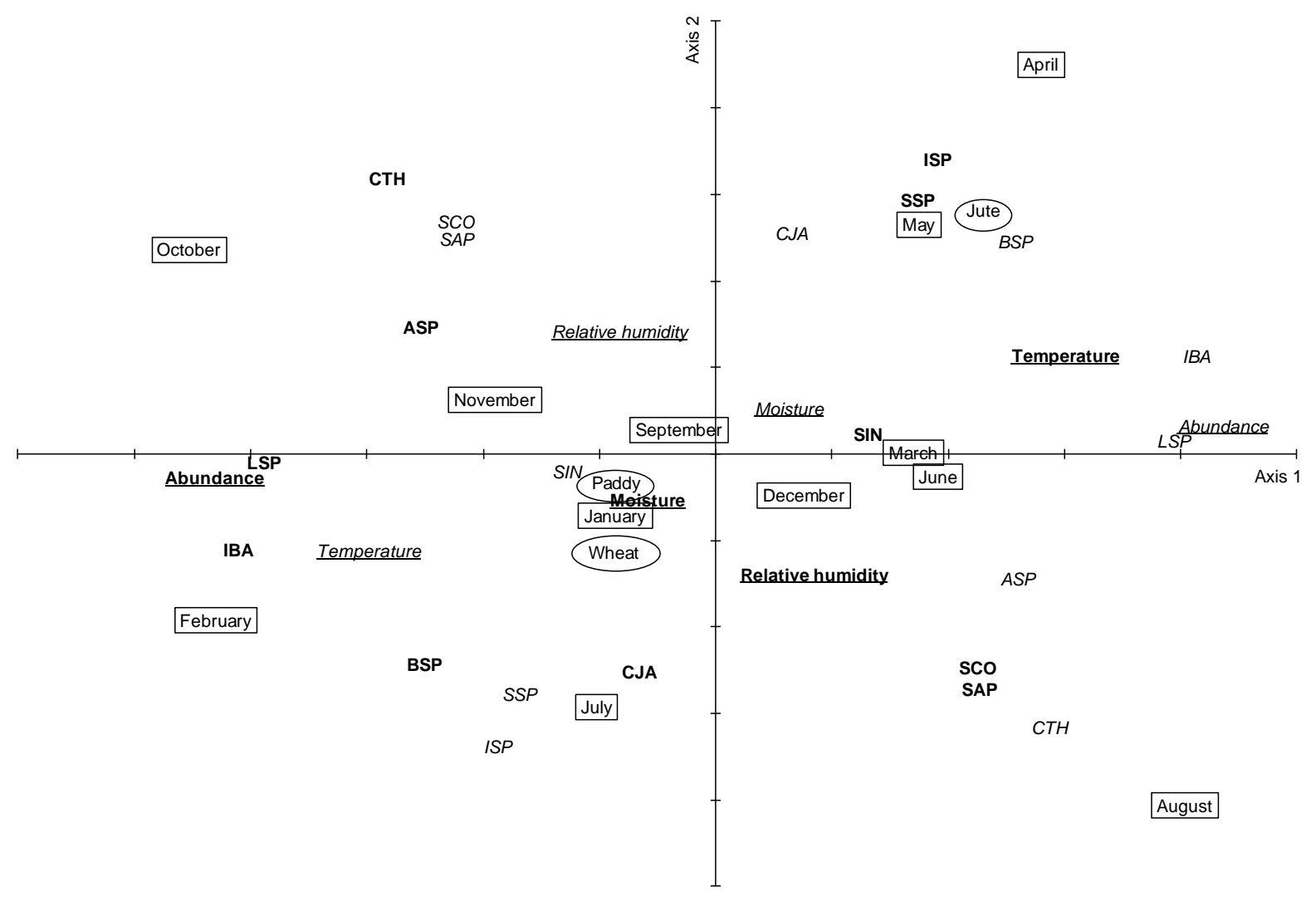

Fig. 1 


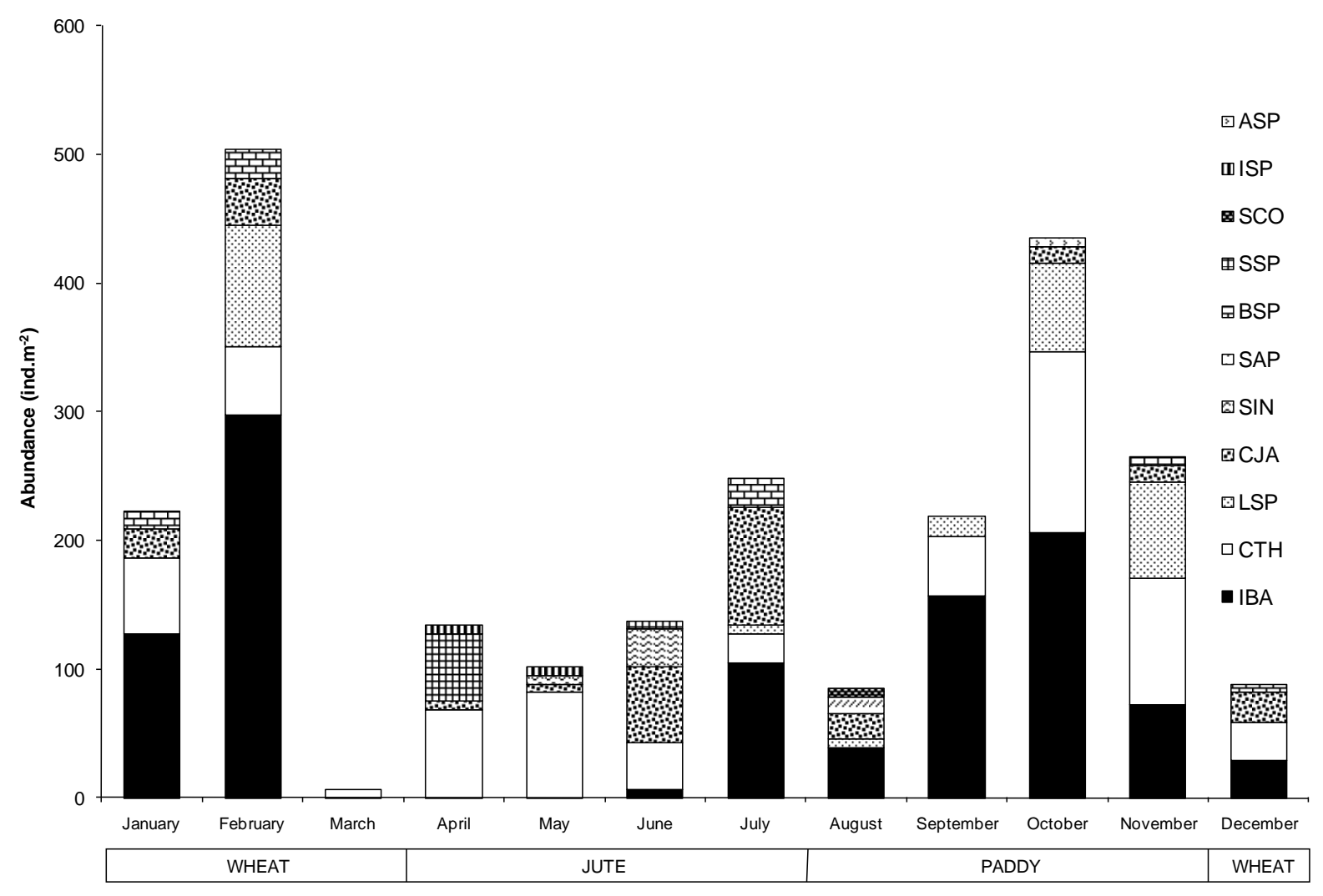

Fig. 2 


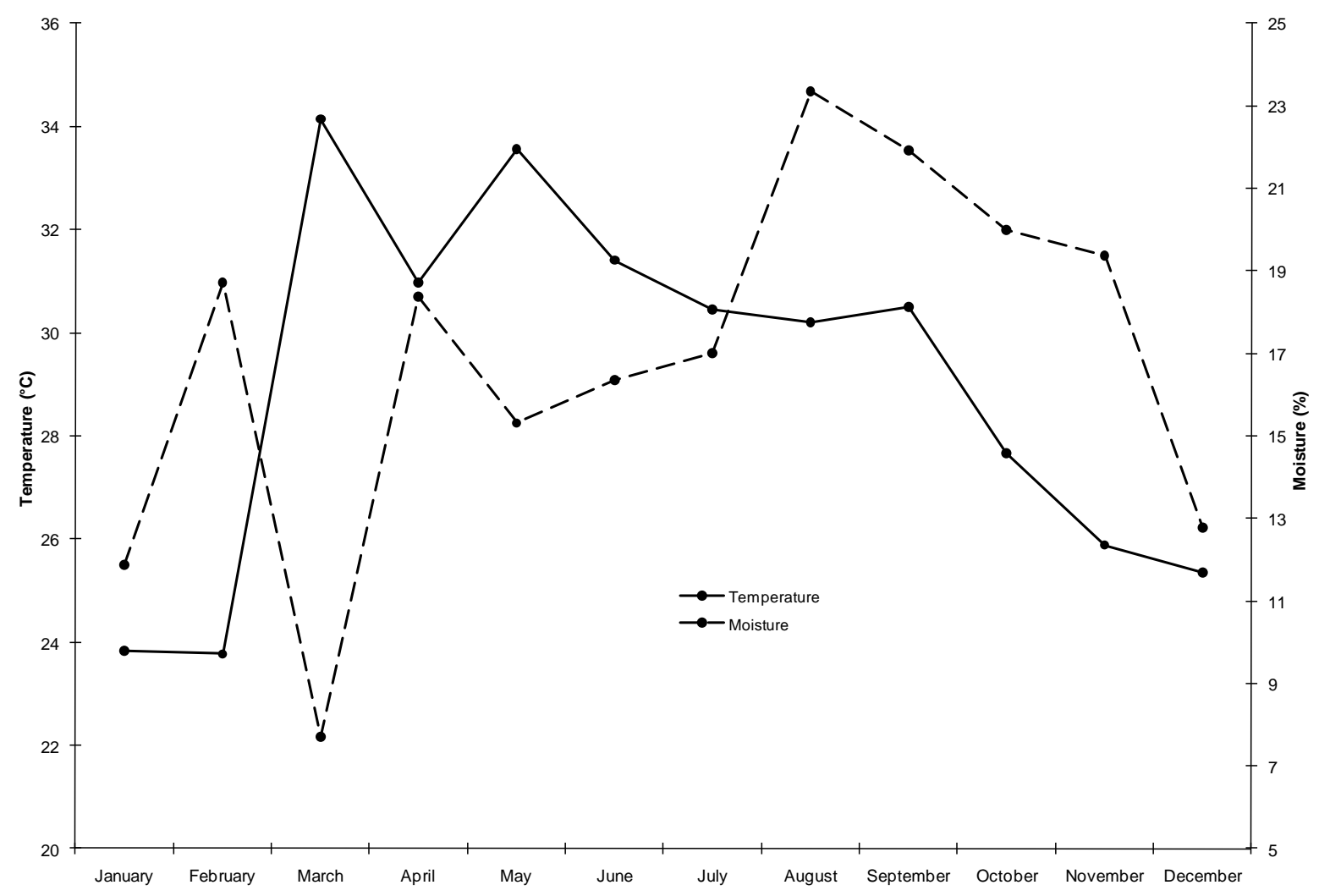

Fig. 3 


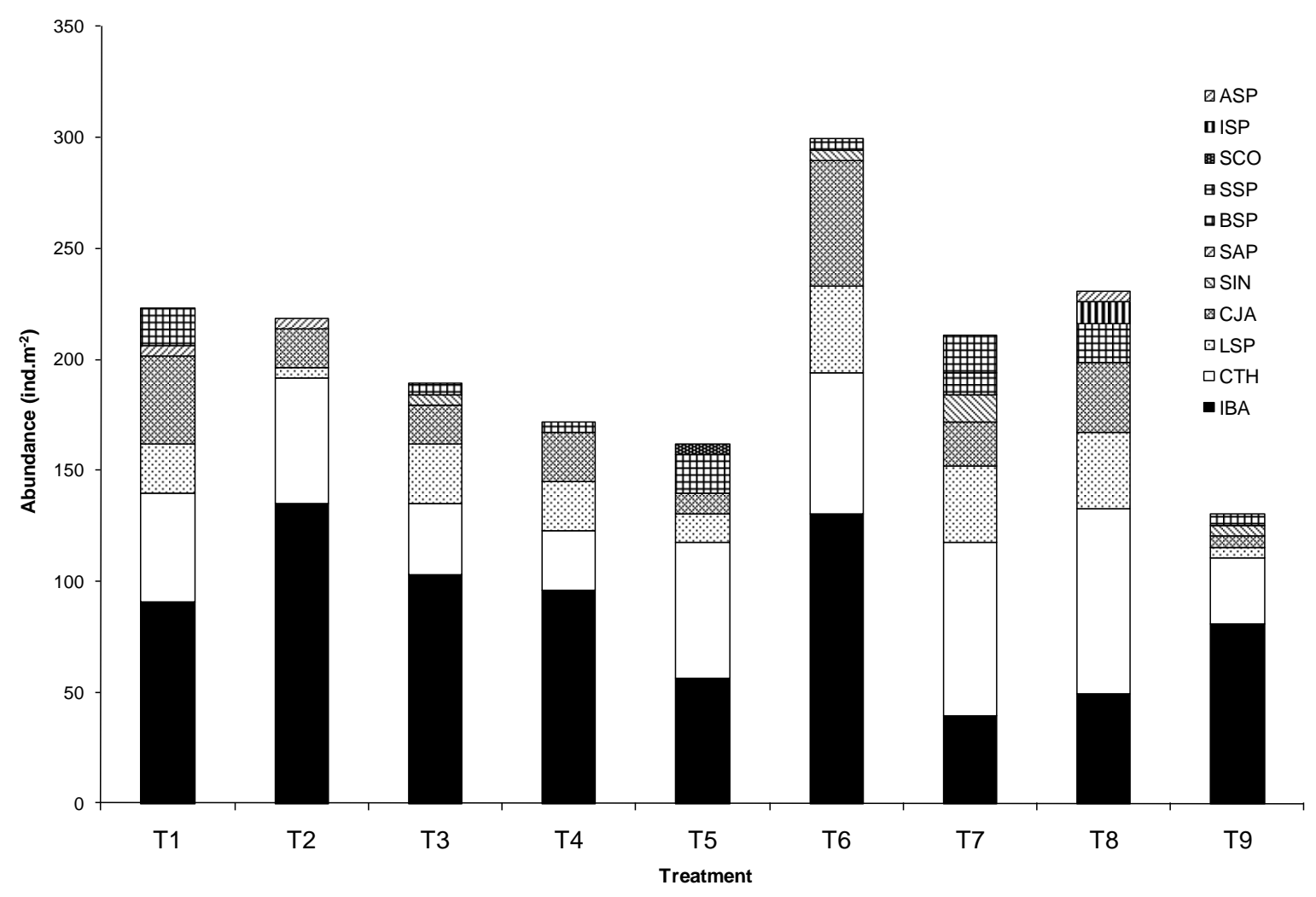

Fig. 4 